\begin{tabular}{|c|c|}
\hline $\begin{array}{c}\text { European Association for the } \\
\text { Development of Renewable Energies, Environment } \\
\text { and Power Quality (EA4EPQ) }\end{array}$ & $\begin{array}{c}\text { International Conference on Renewable Energies and Power Quality } \\
\text { (ICREPQ'12) }\end{array}$ \\
Santiago de Compostela (Spain), 28th to 30th March, 2012
\end{tabular}

\title{
Comparison of Multicarrier PWM Strategies for Five-level Z-Source Diode- Clamped Inverter for On-Grid Renewable Energies Applications
}

\author{
M. Nasiri ${ }^{1}$, G. B. Gharehpetian ${ }^{1}$ and J. Milimonfared ${ }^{1}$ \\ ${ }^{1}$ Electrical Engineering Department \\ Amirkabir University of Technology \\ Tehran, Iran \\ Phone number:+0098 2164543341, e-mail: $\underline{\text { M_nasiri@aut.ac.ir, grptian@aut.ac.ir, }}$ monfared@aut.ac.ir
}

\begin{abstract}
Multilevel Z-source inverters have been proposed as a solution for $\mathrm{HV}$ applications. This type of inverters decreases the Total Harmonic Distortion (THD) and has a good performance for different applications such as Flexible AC Transmission Systems, power quality improvement and connecting renewable energy resources to the network. This paper compares several alternative carrier disposition PWM strategies for a five-level Z-source diode-clamped inverter. These strategies are simulated in MATLAB/Simulink. The simulation results illustrate that using Phase Disposition (PD) method, the voltage THD decreases considerably. Also, Alternative Phase Opposition Disposition (APOD) method increases the voltage magnitude more than PD method. Both methods can be effectively used for connecting renewable energy sources to the power grid.
\end{abstract}

\section{Key words}

Multicarrier PWM strategies, multilevel inverter, renewable energies, Z-Source inverter.

\section{Introduction}

In recent years, multilevel inverters have drawn significant attention in research and high power applications such as Flexible AC Transmission Systems (FACTS), renewable energy resources, power quality devices, etc[1]-[4].

Such power converters have been the prime focus of power electronic researches in order to improve their performance, reliable, energy efficient at minimum cost. The important task of multilevel inverter is producing a sinusoidal voltage waveform from DC sources.

The major advantages of multilevel inverters are:
a) "High voltage capability with voltage limited devices;
b) Low harmonic distortion;
c) Reduced switching losses;
d) Increased efficiency;
e) Good electromagnetic compatibility" [5].

Among several reported topologies, diode-clamped multilevel inverter, cascaded H-bridge multilevel inverter and flying capacitor multilevel inverter are very used [6]. To control these multilevel inverters several carrier-based PWM strategies and space vector PWM (SVPWM) have been reported [7]-[8]. Some other methods such as harmonic optimization attempt to reduce or eliminate harmonic in multilevel inverters [9].

Traditional inverters are known to produce an output voltage that is lower than the DC source voltage. In order to reach boosted voltage with available switching devices Z-Source inverters were invented in 2003 [10].

This structure uses unique $\mathrm{X}$-shaped inductancecapacitance (LC) impedance network that is connected between the DC link and the AC side. There are shootthrough states in Z-source inverter. These states boost voltage and LC impedance network prevent short circuit problems. Recently, new topologies of multilevel Zsource are introduced [1], [11]-[13].

These structures are used in clean energy harnessing such as photovoltaic (PV) arrays, fuel cells, etc that have low DC voltage [13]. Some papers attempt to introduce special structures to reduce the number of elements of multilevel Z-source inverter [14].

In this paper, a five-level Z-source diode-clamped inverter is used to introduce advantages and disadvantages of each multicarrier PWM strategy.

This paper is structured as follows: In section II, multilevel inverters will be explained briefly. Section III, introduces some multicarrier Pulse Width Modulation (PWM) strategies. In Section IV, s Z-source inverters are explained. In section $\mathrm{V}$, the simulation results are shown. Finally, in section VI, the comparison results are summarized in the conclusion.

\section{Multilevel Inverters}

There are several topologies of multilevel inverters, i.e., Diode-clamped multilevel inverter (DCMI), cascaded $\mathrm{H}$ bridge multilevel inverter (CMI) and flying capacitor 


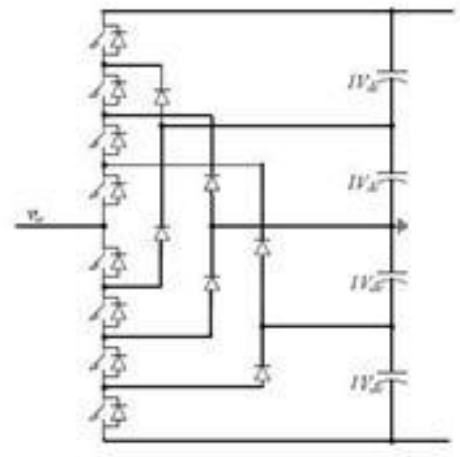

(a)

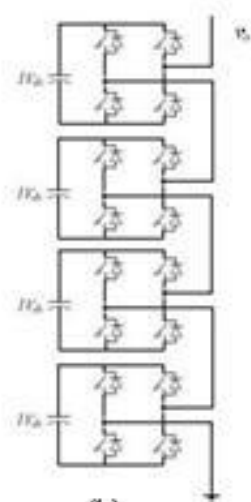

(b)

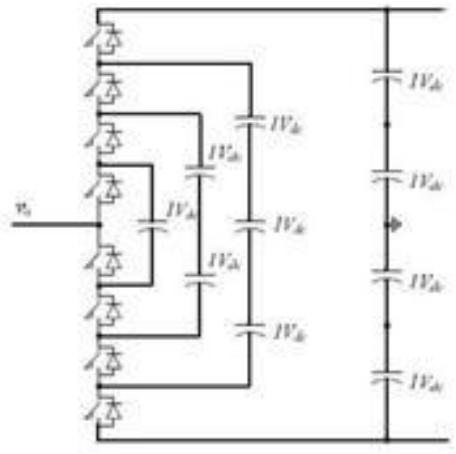

(c)

Fig. 1. (a) Diode-clamped multilevel inverter (DCMI) (b) cascaded H-bridge multilevel inverter (CMI) and (c) flying capacitor multilevel inverter $(\mathrm{FCI})$

multilevel inverter (FCI) are some traditional structures that are shown in Fig. 1.The CMI uses series string of single-phase full-bridge inverters to construct multilevel three phase legs. The advantages of this structure are its the simple modulation, control, and protection.

The DCMI uses a single DC link that is subdivided into $N-1$ voltage levels (in $\mathrm{N}$ level inverter) by a series string of capacitors. A set of semiconductor switches and diodes allows each phase-leg output to be switched to any of these voltage levels. This inverter is used in medium voltage levels.

\section{Z-Source Inverters}

There are three inverter structures; Voltage-source inverter, Current-source inverter and Z-source inverter.

Voltage-source inverter and Current-source inverter have several drawbacks in Renewable Energy Resources application such as cost increase, low efficiency, inverter overrating and need of an output LC filter which causes control complexity [10],[13].

To remove the problems of Voltage-source inverter and Current-source inverter, Z-source inverter has been introduced. Fig. 2 shows the general Z-source inverter structure. It employs a unique impedance circuit to connect the inverter main circuit to the power source. This circuit consists of a split-inductor or two separate inductors $L_{1}$ and $L_{2}$, capacitors $C_{1}$ and $C_{2}$ connected in $\mathrm{X}$ shape. This circuit is employed to provide an impedance source coupling the inverter to the DC source or another converter. The DC source can be a battery, diode rectifier, fuel cell, etc.

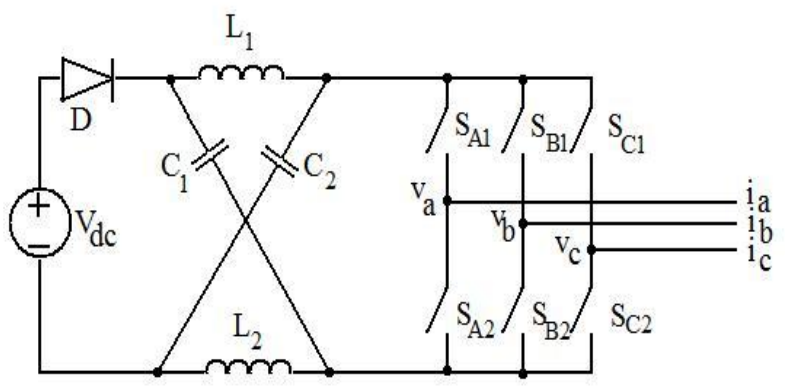

Fig. 2: General Z-source inverter structure.
To illustrate the operating principles and control of the multilevel Z-source inverter, let us briefly introduce the control method of a two-level Z-source inverter. The three-phase Z-source inverter has nine switche states unlike the three-phase voltage source inverter that has eight. The three-phase Z-source inverter has one extra zero state that it is called the shoot-through zero state. It can be generated by seven different ways: shoot-through via any one phase leg, contributions of any two phase legs, and all three phase legs. This state provides the buckboost feature to the inverter.

As explained in [10], for a two-level Z-source inverter, there are two equivalent circuits. The resulting full shootthrough equivalent circuit is shown in Fig. 3a, where the input diode is reversed biasing. In non-shoot-through state, the stored energy in the $\mathrm{Z}$-source inductors is released for consumption in the load. The resulting equivalent circuit is shown in Fig.3b, where load is represented by a current source, and the input diode is in conducting mode.

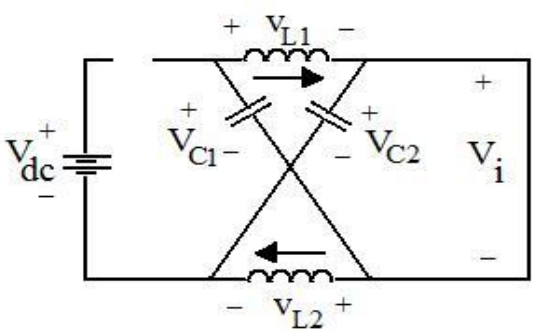

(a)

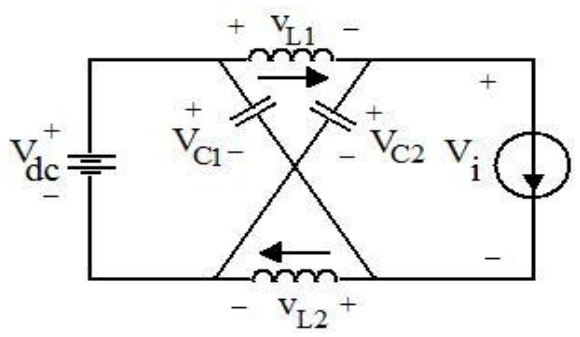

(b)

Fig. 3: (a) Full shoot-through and (b) non-shoot-through equivalent circuits 
Suppose that the capacitor voltage $V_{C}$, the dc-link voltage $\hat{v}_{i}$ and peak ac output voltage $\hat{v}_{a c}$ are, respectively, derived as [10],

$$
\begin{gathered}
V_{C}=\frac{1-\frac{T_{0}}{T}}{1-2 \frac{T_{0}}{T}} V_{d c} \\
\hat{v}_{i}=2 V_{C}-V_{d c}=\frac{V_{d c}}{1-2 \frac{T_{0} / T}{T}}=B V_{d c} \\
\hat{v}_{a c}=M \cdot \frac{\hat{v}_{i}}{2}=\frac{M B V_{d c}}{2}
\end{gathered}
$$

where, $T_{0}$, is the shoot-through duration in a switching cycle $\mathrm{T}, B \geq 1$ is the boost factor and $\mathrm{M}$ is the inverter modulation ratio.

The Z-source structure can be added to multilevel inverter to boost voltage. In this paper, a special structure of fivelevel Z-source diode-clamped inverter is used that is shown in Fig.4. This structure has two $X$ shaped LC impedance networks instead of four LC impedance networks. In addition to the full shoot-through state, the partial shoot-through states can be assumed by Z-source diode-clamped inverter. The equivalent circuits for representing these partial shoot-through states are shown in Fig.5. The non-shoot-through state equivalent circuit is shown in Fig. 5a.The first partial shoot-through state shown in Fig. 5b, when switches SX1, SX2, SX3, SX4 and $\mathrm{SX}^{\prime} 1$ are turned on with $\mathrm{DA}^{\prime} 1$ and $\mathrm{D} 1$ conducting. Also, Fig.5c shows the lower partial shoot-through state [14]. The capacitor voltage $V_{C}$, the peak dc-link voltage $\hat{v}_{i}$ and peak ac output voltage $\hat{v}_{a c}$ are two times of Eq. (1) to (3). The details of controlling strategies are given in the following sections.

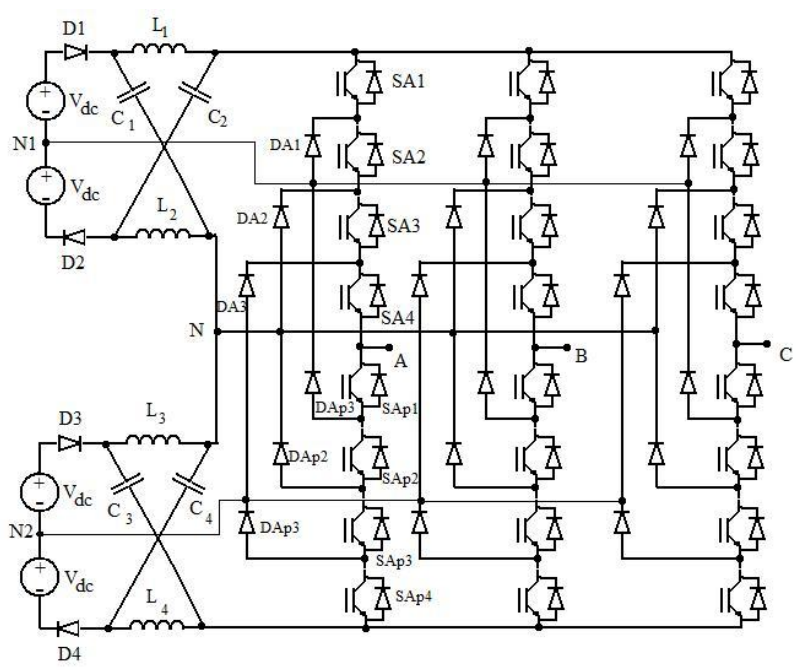

Fig. 4: Five-level Z-source diode-clamped inverter.

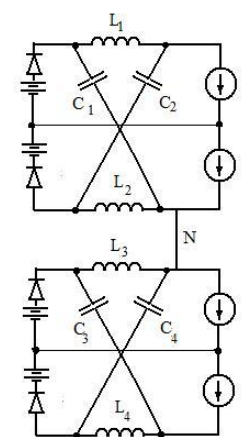

(a)

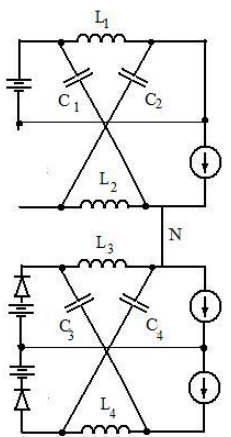

(b)

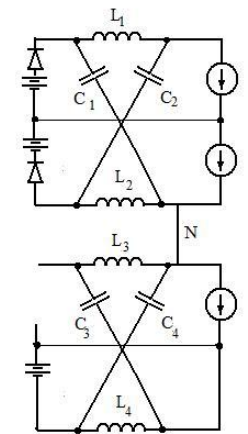

(c)
Fig. 5: (a) Non-shoot-through state equivalent circuit, (b) upper partial shoot-through state equivalent circuit and (c) lower partial shoot-through state equivalent circuit.

\section{Multicarrier PWM Strategies}

There are four carrier-based PWM schemes for mentioned topologies:

a) Alternative Phase Opposition Disposition (APOD), where each carrier signal is phase shifted by $180^{\circ}$ from adjacent carrier;

b) Phase Opposition Disposition (POD), where the carrier signals above the sinusoidal reference zero point are $180^{\circ}$ out of phase with those below the zero point;

c) Phase Disposition (PD), where all carrier signals are in phase;

d) Phase-Shifted Carrier PWM (PSCPWM), where shift $N$ carrier waves by $360^{\circ} / N$ in order to provide $N+1$ level $P W M$ pattern in each phase. For the cascaded inverter, PSCPWM is the common strategy [15]-[16].

Fig. 6 shows carrier-based PWM strategies. APOD, POD and PD modulations are used to control most of multilevel inverter structures but PSCPWM is used in the cascaded inverter.

There are several methods to control Z-source inverter that can be classified into shoot-through states insertion methods. In the first method, six shoot-through states will be inserted in one switching cycle. The second method two shoot-through states will be directly inserted in one cycle [17]. In this paper, the second method is applied to carrier-based PWM strategies, APOD, POD and PD modulations. The simulation results will be presented in next section.

\section{Simulation Results}

For comparison, the carrier-based PWM strategies that are applied to a five-level Z-source inverter. The simulations have been carried out in MATLAB/Simulink. Major system parameters are listed in Table I. 


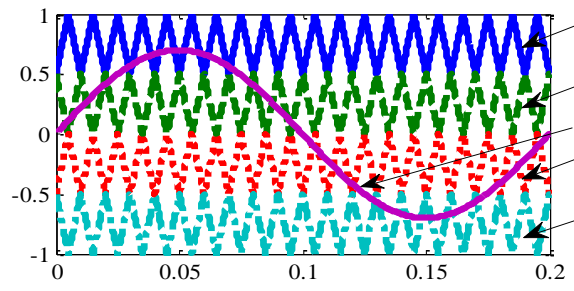

(a)

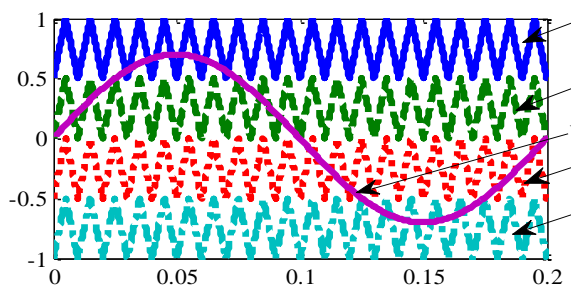

(c)

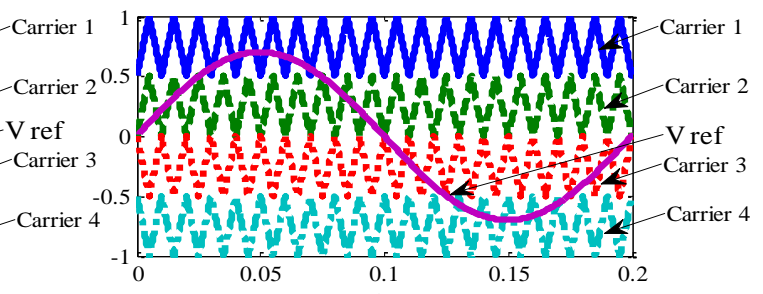

(b)

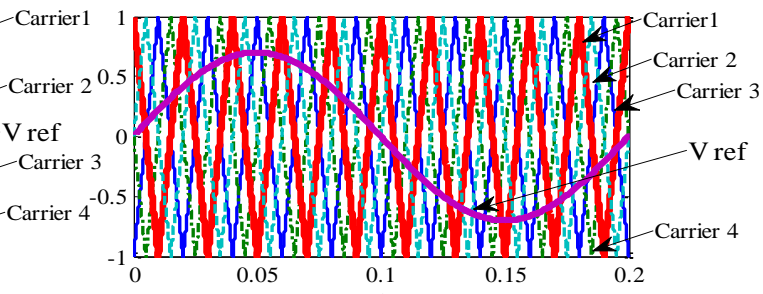

(d)

Fig. 6: Carrier-based PWM strategies, (a) APOD modulation, (b) POD modulation, (c) PD modulation and (d) PSCPWM modulation.

Table I. - System parameters

\begin{tabular}{|l|l|}
\hline & \multicolumn{1}{|c|}{ PARAMETER } \\
\hline Source & $V_{d c}=40 \mathrm{~V}$ \\
\hline \multirow{4}{*}{ LC Network } & $L=4.3 \mathrm{mH}$ \\
\cline { 2 - 2 } & $C=1 \mathrm{mF}$ \\
\hline \multirow{5}{*}{ Load } & $f_{c}=10 \mathrm{kHz}$ \\
\cline { 2 - 2 } & $f_{r}=50 \mathrm{~Hz}$ \\
\cline { 2 - 2 } & $M=0.7 \times 1.15$ \\
\cline { 2 - 2 } & $T_{0} / \mathrm{T}=0.3$ \\
\hline & $L=10 \mathrm{mH}$ \\
\cline { 2 - 2 } & $R=53 \Omega$ \\
\hline
\end{tabular}

Fig. 7 shows upper partial shoot-through states in a single-leg of inverter. As shown there is not the full shoot-through state in these PWM strategies.

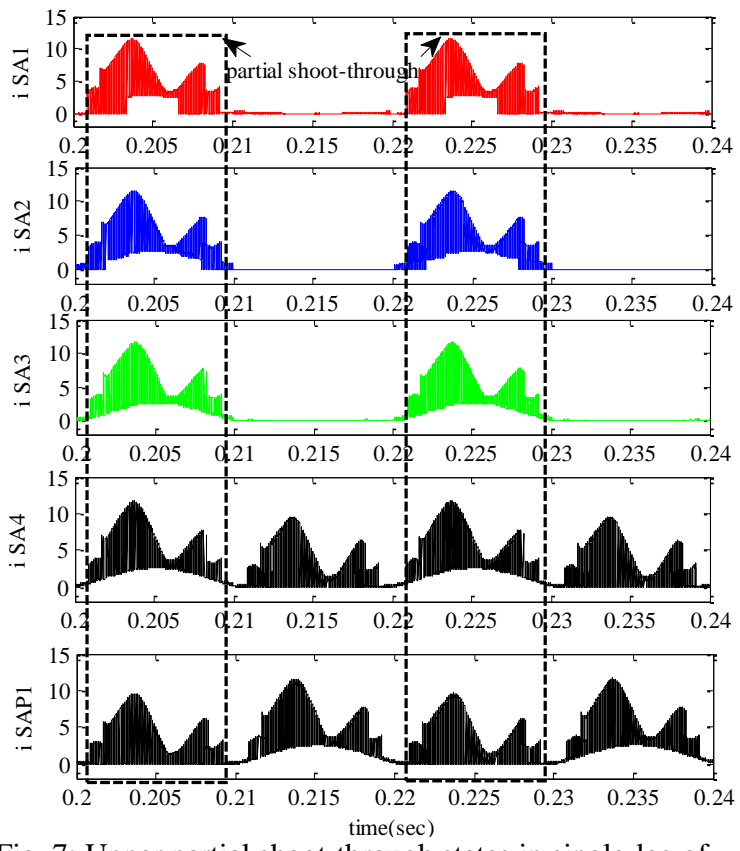

Fig. 7: Upper partial shoot-through states in single-leg of inverter.
Figs.(8),(9) and (10) show Line-to-Line and Line-Neutral voltages, load current and one of the LC network capacitor voltages that controlled by PD, POD and APOD modulation with two partial shoot-through states in one switching cycle.

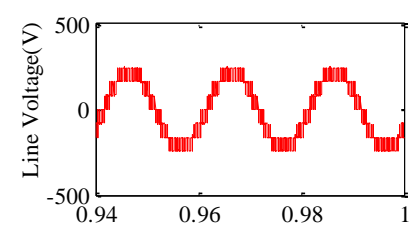

(a)

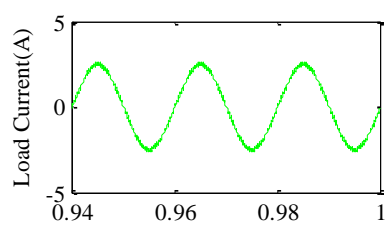

(c)

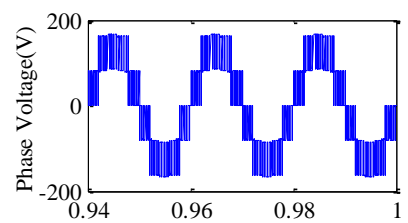

(b)

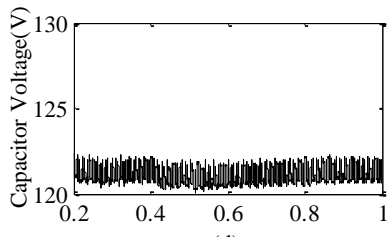

(d)
Fig. 8: PD modulation, (a) line-to-line voltage, (b) phase voltage, (c) load current and (d) capacitor voltage.

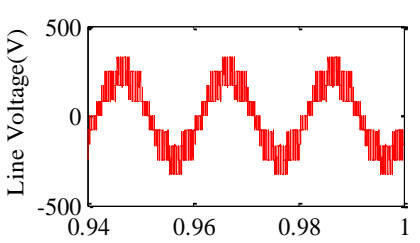

(a)

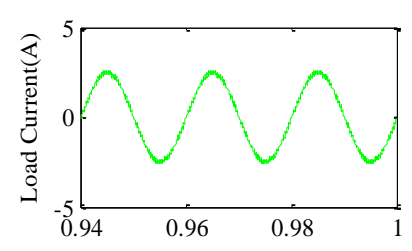

(c)

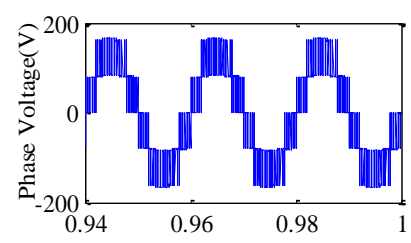

(b)

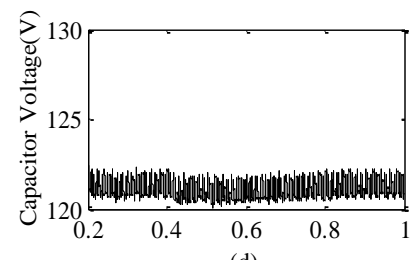

(d)
Fig. 9: POD modulation, (a) line-to-line voltage, (b) phase voltage, (c) load current and (d) capacitor voltage. 
Table II: Simulation results of different methods.

\begin{tabular}{|l|l|l|l|l|l|l|c|}
\hline \multirow{2}{*}{ Method } & \multicolumn{2}{|l}{ Line-to-line voltage } & Phase voltage & Load current & Capacitor voltage \\
\cline { 2 - 8 } & Amplitude(V) & THD (\%) & Amplitude(V) & $\begin{array}{c}\text { THD } \\
(\%)\end{array}$ & Amplitude (A) & THD (\%) & Amplitude(V) \\
\hline PD & 226.7 & 21.59 & 130.9 & 37.82 & 2.465 & 3.06 & 122 \\
\hline POD & 226.7 & 35.07 & 130.9 & 37.82 & 2.465 & 3.08 & 122 \\
\hline APOD & 235.6 & 29.26 & 136 & 37.81 & 2.562 & 3.37 & 125 \\
\hline
\end{tabular}
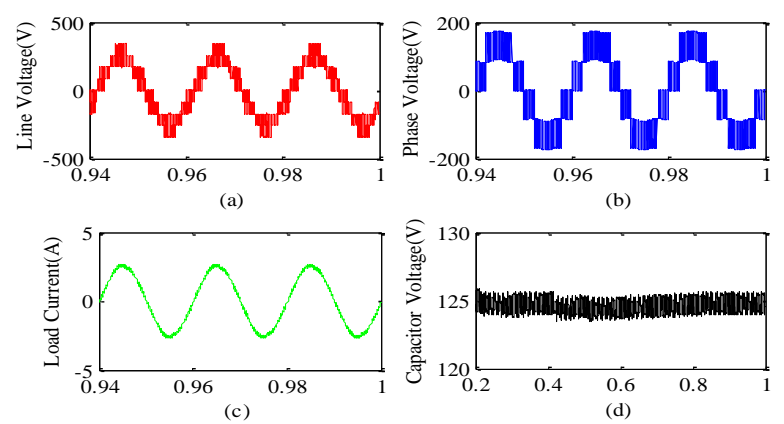

Fig. 10: APOD modulation, (a) line-to-line voltage, (b) phase voltage, (c) load current and (d) Capacitor voltage.

In Table II, the amplitude and the THD of the line-to-line and line-neutral voltages and the load current are presented.

As given in Table II, it is clearly deduced that APD modulation will boost the voltage more than POD and PD modulation in the same condition. Also, Line-to-Line voltage harmonics increase in PD, APOD and POD, respectively. Considering the aforementioned advantages, APOD modulation is a suitable technique to be applied in this type of converters.

\section{Conclusion}

This paper has compared three multicarrier PWM strategies that can be applied to five-level Z-source diode clamped inverters. The THD of the phase voltage and load current in three methods has been determined. Comparing the line-to-line voltages in three methods, it can be seen that the highest THD happens in POD method and the lowest one occurs in PD method. Comparing the DC capacitor voltage of the LC impedance network, it can be said that the APOD modulation, in the same condition, will boost the voltage more than POD and PD modulation techniques. The simulation results illustrate that using Phase Disposition (PD) method decreases the voltage THD considerably. Also, Alternative Phase Opposition Disposition (APOD) method increases the voltage more than the PD method. Both methods can be effectively used in on-grid renewable energy applications.

\section{References}

[1] Banaei, M.R. Dehghanzadeh, A.R., "DVR Based Cascaded Multilevel Z-Source Inverter," Power and Energy (PECon), 2010 IEEE International Conference on, pp. 51-56, Nov. 29 2010-Dec. 12010.

[2] Khomfoi, S.; Praisuwanna, N.; Tolbert, L.M.," A Hybrid Cascaded Multilevel Inverter Application for Renewable Energy Resources Including a Reconfiguration Technique"
Energy Conversion Congress and Exposition (ECCE), 2010 IEEE , pp. 3998 - 4005, 2010.

[3] Rahim, N.A.; Selvaraj, J., "Multistring Five-Level Inverter With Novel PWM Control Scheme for PV Application," Industrial Electronics, IEEE Transactions on , vol. 57, pp. $2111-2123,2010$.

[4] Waware, M.; Agarwal, P., "Use of Multilevel Inverter for Elimination of Harmonics in High Voltage Systems," Computer and Automation Engineering (ICCAE), 2010 The 2nd International Conference on , vol. 2, pp. 311 - 315, 2010. [5] Irfan, M.M.; Prasad, P.H.K.; Rao, P.V.; "Simulation of Five-level Five-phase SVPWM Voltage Source Inverter," Power, Control and Embedded Systems (ICPCES), 2010 International Conference on , pp.1-5,2010.

[6] Peng, F.Z.; Wei Qian; Dong Cao; "Recent Advances in Multilevel Converter/Inverter Topologies and Applications," Power Electronics Conference (IPEC), 2010 International ,pp. 492-501, 2010.

[7] McGrath, B.P.; Holmes, D.G.; "Multicarrier PWM Strategies for Multilevel Inverters," Industrial Electronics, IEEE Transactions on, vol. 49, pp. 858-867, 2002.

[8] M. G. Hosseini Aghdam, S. H. Fathi, G. B. Gharehpetian, "Elimination of Harmonics in a Multi-level Inverter with Unequal DC Sources Using the Homotopy Algorithm," 2007 IEEE International Symposium on Industrial Electronics(IEEE ISIE 2007), Vigo, Spain, pp.578-583, June 4-7,2007.

[9] Hosseini Aghdam, M.G.; Fathi, S.H.; Gharehpetian, G.B.; " Comparison of OMTHD and OHSW harmonic Optimization Techniques in Multi-Level Voltage-Source Inverter with nonequal DC Sources," Power Electronics, 2007. ICPE '07. 7th Internatonal Conference on, pp. 587-591, 2007.

[10] Fang Zheng Peng;“" Z-Source Inverter," Industry Applications, IEEE Transactions on ,Vol.39 , Issue.2 , pp. 504 $-510,2003$.

[11] Poh Chiang Loh; Feng Gao; Blaabjerg, F.; Shi Yun Charmaine Feng; Kong Ngai Jamies Soon , " PulsewidthModulated Z-Source Neutral-Point-Clamped Inverter," Industry Applications, IEEE Transactions on, vol. 43, pp. 1295-1308, 2007.

[12]Ding Li; Feng Gao; Poh Chiang Loh; Miao Zhu; Blaabjerg, F. " Cascaded Impedance Networks for NPC Inverter,” IPEC, 2010 Conference Proceedings, pp. 1176$1180,2010$.

[13] Fang Zheng Peng and Yi Huang Michigan, “ Z-Source Inverter for Power Conditioning and Utility Interface of Renewable Energy Sources," IEEE Trans, Vol. 23, no. 4, 2004.

[14]Gao, F.; Loh, P.C.; Blaabjerg, F.; Teodorescu, R.; Vilathgamuwa, D.M. " Five-level Z-source diode-clamped inverter," Power Electronics, IET, vol. 3, pp. 500-510,2010. [15] Y. Liang and C. O. Nwankpa, "New type of STATCOM based on cascading voltage source inverters with phase-shifted unipolar SPWM," in Conf. Rec. IEEE-LAS Annu. Meeting, 1998, pp. 1447-1453.

[16]McGrath, B.P.; Holmes, D.G. " A Comparsion of Multicarrier PWM Strategies for Cascaded and Neutral Point Clamped Multilevel Inverters," Power Electronics Specialists Conference, 2000. PESC 00. 2000 IEEE 31st Annual, vol. 2, pp. 674-679, 2000.

[17] Husodo, B.Y.; Anwari, M.; Ayob, S.M.; Taufik, “ Analysis and Simulations of Z-Source Inverter Control Methods," IPEC, 2010 Conference Proceedings, pp. 699-704, 2010. 